UDK 311.17:[631.164.6:614.72]-027.541

JEL Classification C15, Q15, Q53, R11

Doi: 10.31767/su. 2(81)2018.02.10

T. V. Kobylynska,

PhD in Economics,

Doctoral Student of Statistics Department,

National Academy of Statistics, Accounting and Audit,

E-mail: kobylynska1976@ukr.net

\title{
Statistical Assessment of Air Emission of Dangerous Substances from Agricultural Activities: the Regional Aspect
}

Results from a statistical assessment of emissions of dangerous substances from agricultural activities of enterprises by region and natural-economic zone of Ukraine are shown. A statistical analysis of emissions of dangerous substances from agricultural activities of enterprises is made by natural-economic zones: Steppe, Forest-Steppe, and Polissia. Ranking of regions by number of agricultural enterprises with emissions of dangerous substances and by scope of emissions is made. It is found that the largest scopes of emitted dangerous substances are generated by enterprises located in Forest-Steppe economic zone of Ukraine.

Key words: scopes of emissions, agricultural production, dangerous substances, natural-economic zones, statistical assessment.

The process of agrarian and land reform has been on in Ukraine for decades. Reforms in the Ukrainian agricultural sector could generate the positive dynamics in agricultural production, but with the by-side effect of the increasing scopes of emissions of dangerous substances from agricultural activities. Environmental protection and reduction of dangerous pollutions from agricultural business is a priority problem of today. The loss of motivation for environment-friendly activities at agricultural enterprises is an inevitable result of weak information support and unsettled legal regulation. Agricultural production depends on the climate. As regards Ukraine, the borders of natural and climatic zones traditional for Ukraine are constantly changing, affecting the productivity in agriculture and forcing producers to rapidly change specialization. Studies of the structure of dangerous emissions from agricultural activities by natural-economic zone are of importance, as users in a transformation economy need quick and high quality statistical data, including the one on scopes of emissions of dangerous substances from agricultural activities by industry, natural-economic zone and category of enterprises. This determines the relevance of studies devoted to statistical assessment of respective indicators.

Issues related with agricultural activities and their environmental effects are addressed by Ukrainian economists such as B. Danilishyn, O. Demianyuk, S. Dorohuntsov, V. Heyets, M. Khvesyk, Yu. Lupenko, V. Messel-Vesyeliak, A. Polyovyi, P. Sabluk, V. Semenov, I. Sivachenko, S. Stepanenko, O. Tatariko, V. Tretiak, V. Fedoriak, M. Fedorov. Problems of statistical assessment of agricultural activities at enterprise level are dealt with V. Danylko, S. Herasymenko, A. Holovach, O. Osaulenko, N. Parfentseva, A. Yerina.

(C) T.V. Kobylynska, 2018
It should be noted, however, that the problem of statistical assessment of environmental effects from agricultural activities of enterprises, including analysis of air emissions by natural and climatic zone, is yet to be solved. Studies of its solutions are becoming increasingly important for the environmental policy, because results of a comparative statistical analysis of agricultural production by natural-economic zone enable for taking sound environmental policy decisions.

The article's objective is to assess emissions of dangerous substances, caused by agricultural activities of enterprises, by natural-economic zone of Ukraine.

The strong emphasis in made on the protection and effective use of natural resources in the Strategy of State Environmental Policy of Ukraine till 2020. First and foremost, it refers to the 5 to 10 percent reduction of arable lands in the regions by exclusion of slopes with steepness of more than three degrees and lands in water protection zones from the arable lands; conservation of degraded, unproductive and industrially polluted agricultural lands, with their subsequent foresting in Forest and Forest-Steppe zones and planting meadows in the steppe zone. But the tillage area and, consequently, the cropland area have nevertheless been increasing year by year. Statistical indicators assessing the environmental component of agricultural activities at enterprise level have obvious scientific interest, because the uncontrolled use of land resources, massscale applications of mineral fertilizers and means for plant protections, use of big agricultural machines on the fields and the boosting output of cattle-breeding sector are factors increasing air emissions of dangerous substances in Ukraine and its regions.

The increasing scopes of agricultural production aggravate environmental problems. As shown in [1-3], they arise from the progressing air pollution and the 
depletion of nearly all the natural resources. A primary objective for the forthcoming period is to implement targeted measures aimed to balance the development of territories and set key economic proportions through sound, effective and innovation-driven economic policy and essential improvements in the existing management system.

The environmental performance covers the following components:

- water (fresh and sea water);

- air;

- flora, fauna;

- land (ground and bowels);

- municipalities.

Statistical assessment of environmental problems can be combined in the two approaches:

1. Assessment of the environmental protection:

- air;

- water;

- land.

2. Assessment of human effects for the environment and the resulting environmental change.

Given the limited statistical data, we have conducted a statistical assessment by use of air indicators measuring dangerous emissions from agricultural activities of enterprises by region and natural-economic zone.

The following natural-economic zones historically exist in Ukraine: Polissia, Forest-Steppe, Northern Steppe and Central Steppe, foothill and highland areas of Carpathians. They differ by climatic, soil and economic conditions, land endowment of the population, which, in overall, has direct or indirect impact on the pattern of agriculture development in Ukraine.

Because the boundaries of natural-economic zones do not always coincide with the boundaries of regions, the abovementioned zones in Ukraine are combined in the following three: Steppe; Forest Steppe, and Polissia that includes foothill and highland areas of Carpathians [4, p. 41-42].

Emissions of dangerous substances are not only an indicator measuring environmental effects from agricultural activities of enterprises (see Figure 1, constructed by the author by data $[5 ; 6]$ ). Their scopes and share in the total dangerous emissions, and the quality of their recording largely determine the indicators of environmental activities of agricultural enterprises. By data from the State Statistics Service of Ukraine, 81587.6 tones of all the categories of

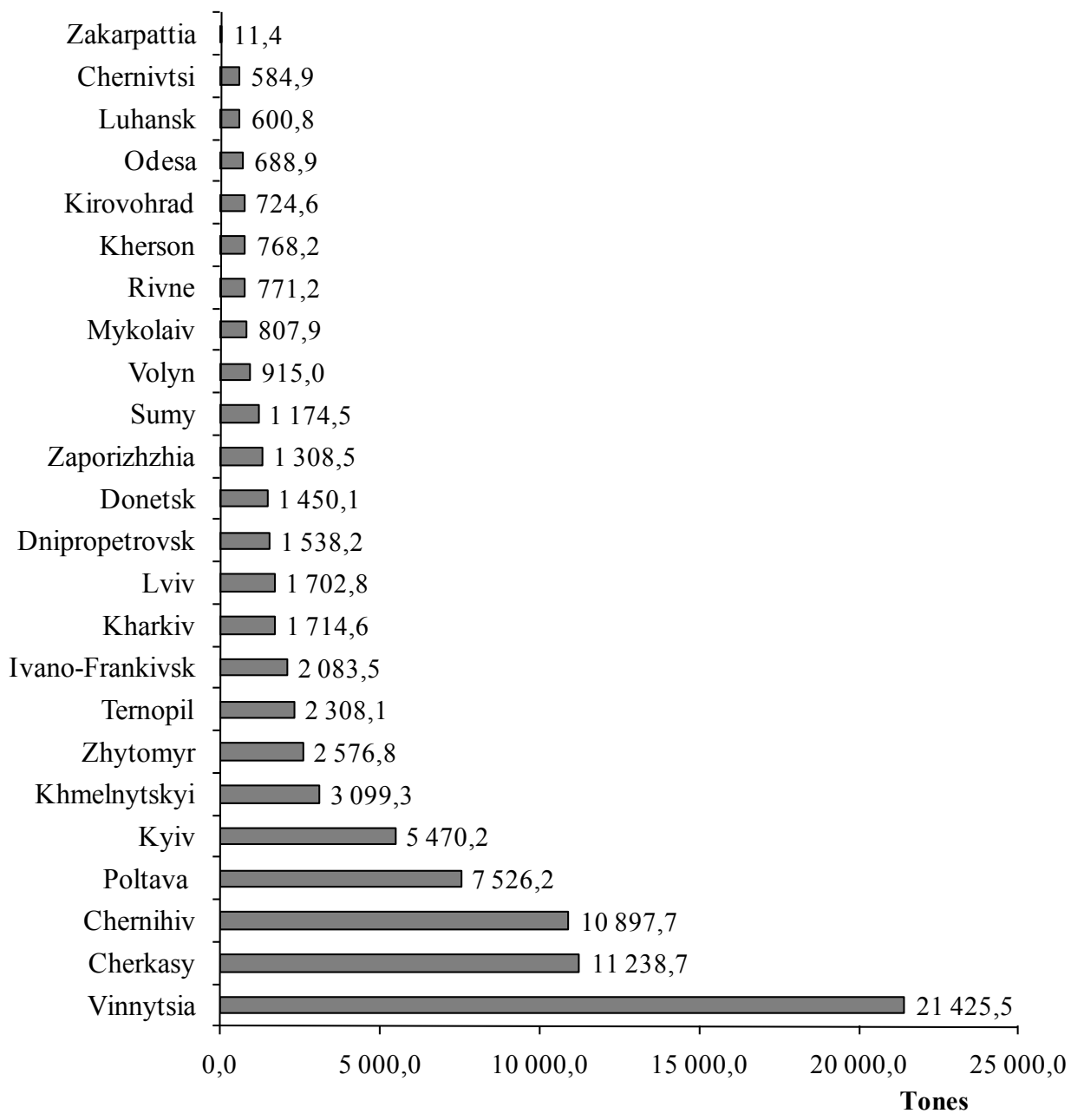

Fig. 1. Emissions of dangerous substances from agricultural activities of Ukrainian enterprises, 2016, tones 
dangerous substances were emitted in the air by agricultural enterprises of Ukraine in 2016.

The scopes of emissions of dangerous substances are a key indicator describing the environmental effects of agricultural activities of enterprises. It can be seen from Figure 1 that the largest scopes were emitted by agricultural enterprises of Vinnytsia region, and the smallest ones were recorded in Zakarpattia region.
The largest number of agrarian producers emitting dangerous substances was recorded in Chernivtsi region (193), and the smallest one was in Zakarpattia region (4) (see Figure 2, constructed by the author by data $[5 ; 6])$.

The regional distribution of agricultural enterprises emitting dangerous substances is uneven because only the enterprises for which emissions of dangerous

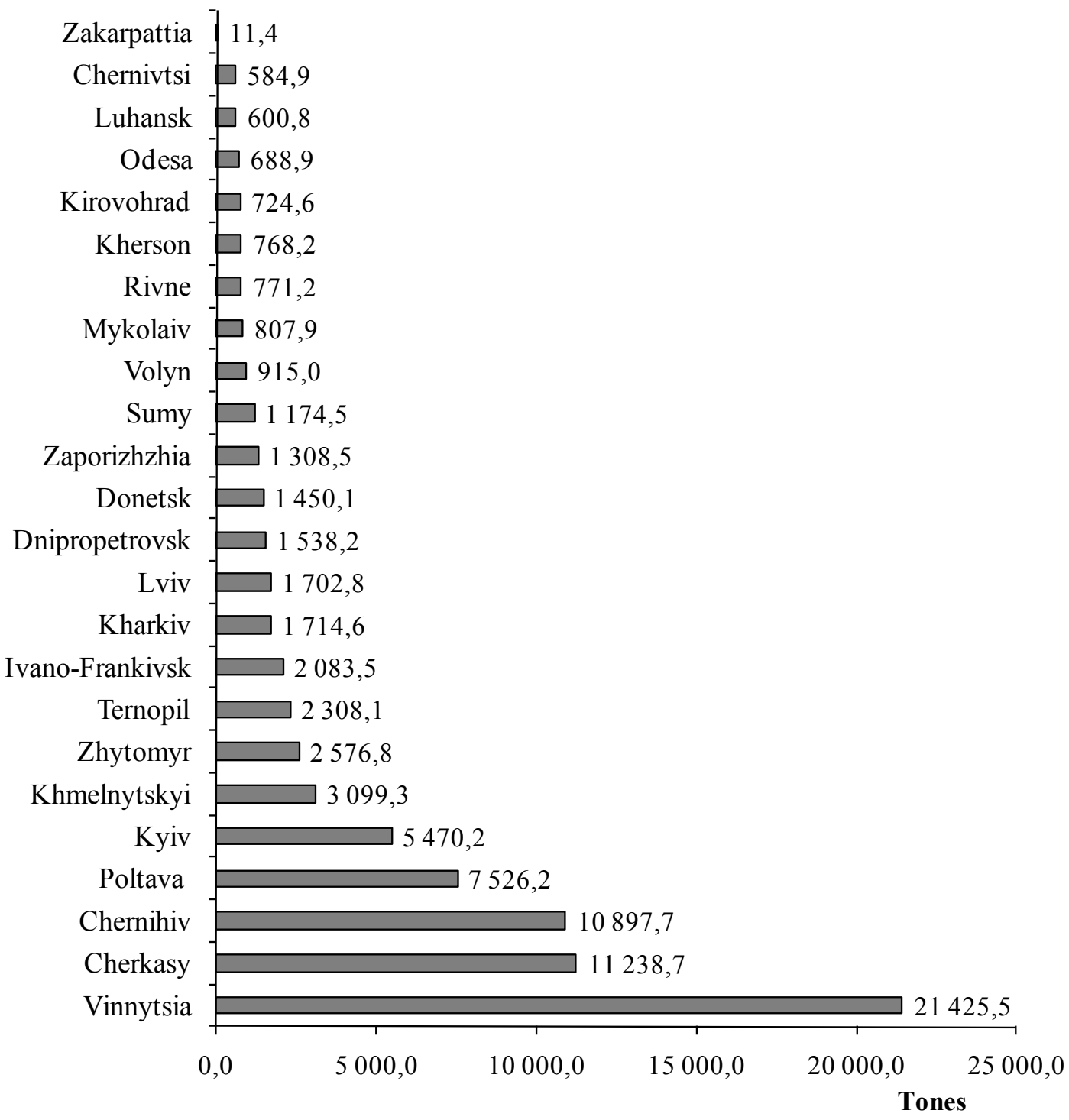

Fig. 2. Numbers of agricultural enterprises in Ukraine emitting dangerous substances, by region, 2016

substances the official record is kept are included in the observation sample $[7 ; 8 ; 9]$.

Figure 3 (constructed by the author by data [6; 10]) shows the dynamics of emissions of dangerous substances by agricultural activities of Ukrainian enteprises, by main category of polluting substances. The largest air emittion was ammonia and carbon oxid.

The most significant pollutant by the volume is carbon dioxide (CO2), whose emissions in 2016 amounted to 878461.6 tons. The distribution of emissions of carbon dioxid by Ukraninian region in 2016 is shown in Figure 4 (constructed by the author by data $[5 ; 6])$. In the period under study, the largest share of $\mathrm{CO} 2$ emissions was recorded for agricultural enterprises of Vinnytsia region, which accounted for more than one fourth of the total emissions (26 percent), whereas Cherkasy and Kyiv regions emitting 13 and 11 percent respectively, that is some less. 


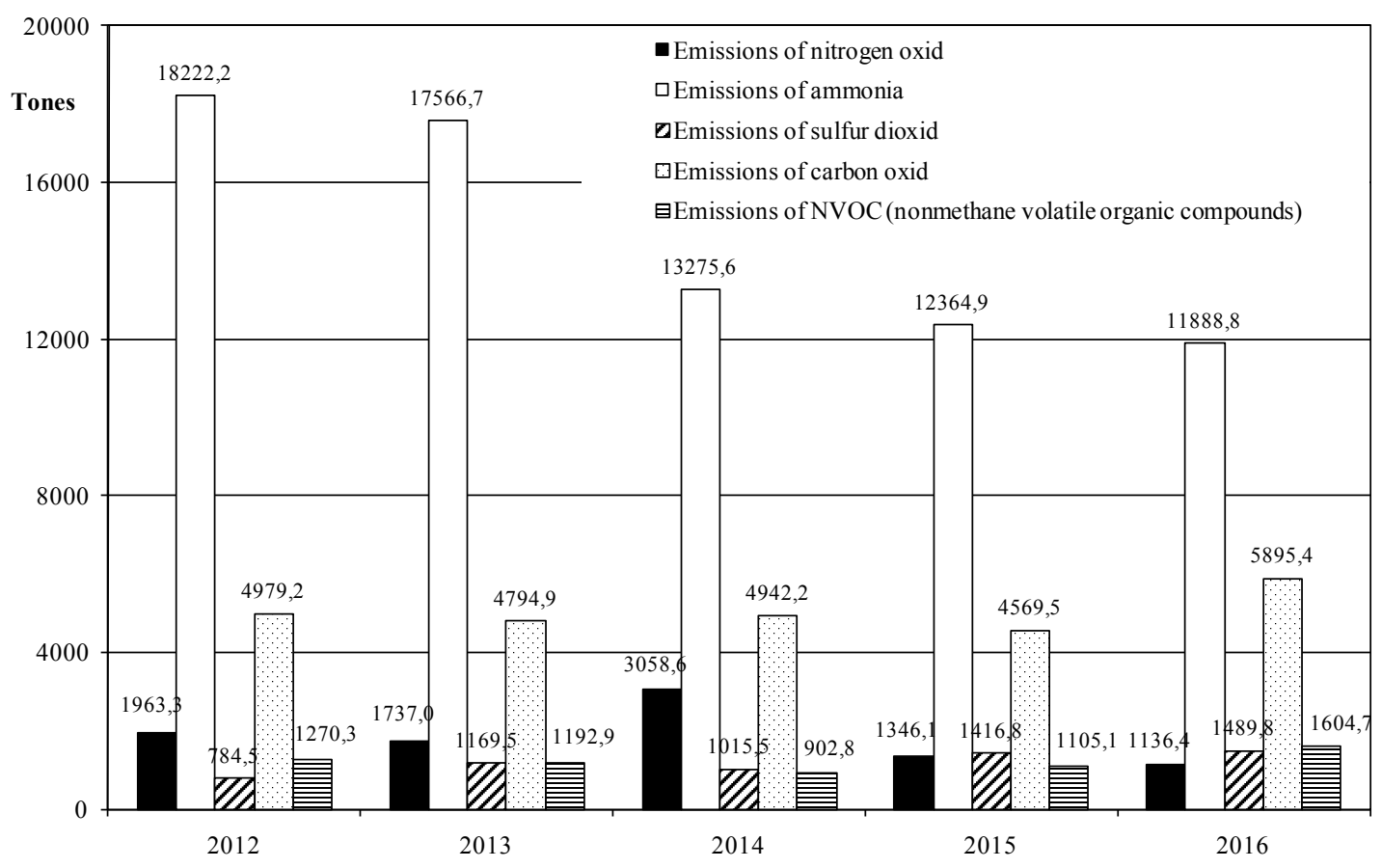

Fig. 3. Emissions of dangerous substances in the air from agricultural enterprises, by category of substance in Ukraine, 2012-2016

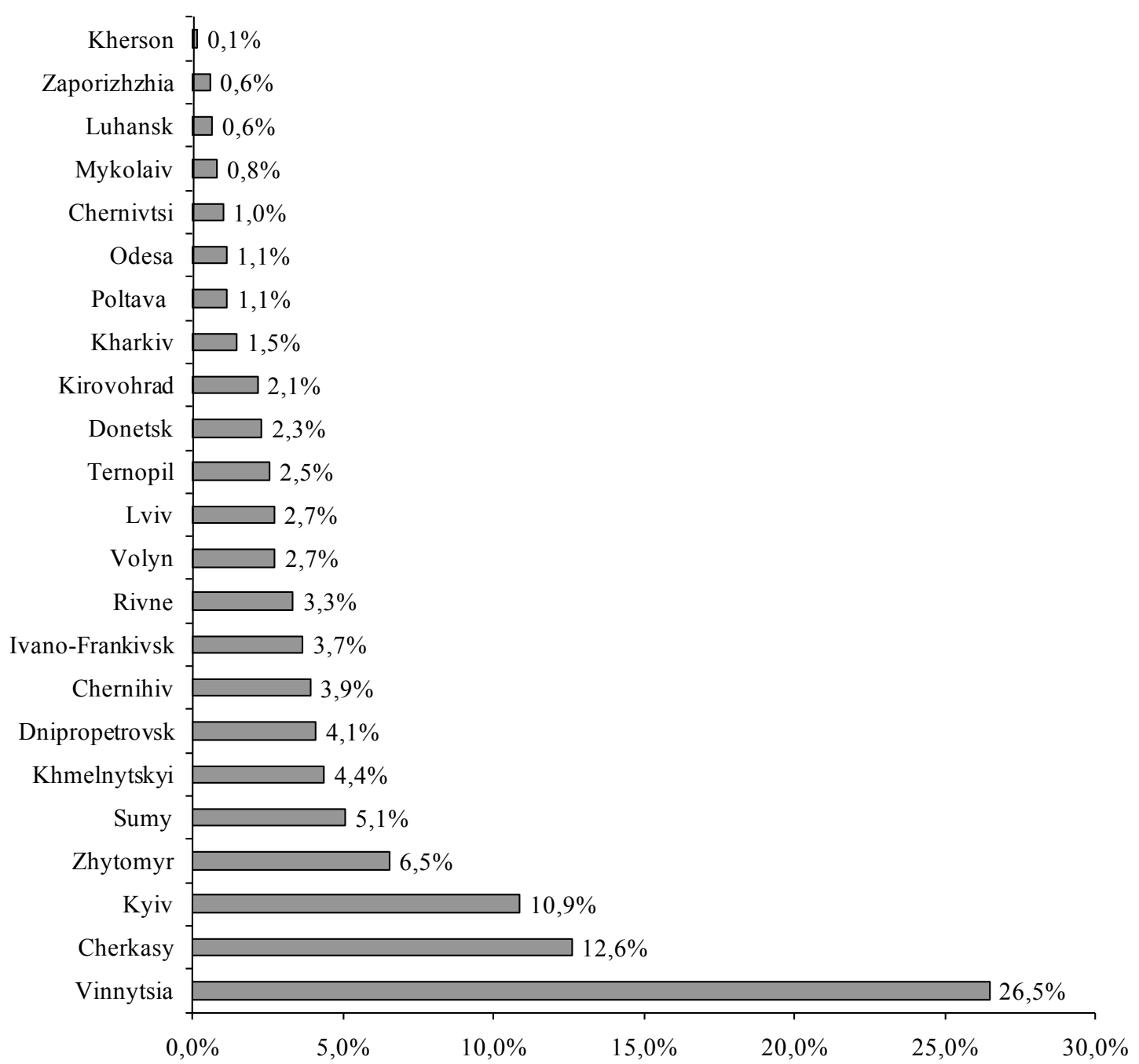

Fig. 4. Emittions of carbon dioxid by Ukrainian region, 2016, \% of the total emission 
The air pollution by degree of chemical danger for a human takes the top position and has severe negative effects for all the environmental components. According to the data from scientific research, air emissions contribute in 80 to 90 percent of the total cancerogenous and non-cancerogenous risks caused by pollution effects.

As noted above, a major part of environmental problems caused by air pollution in regions originates from agricultural sector, namely, due to emissions of methane and ammonia from:
- intestinal fermentation of animals;

- formation, storage and use of dung;

- milk cows;

- other categories of cattle;

- broilers.

The distribution of emittions of dangerous substances such as methane and ammonia, by naturaleconomic zone, region and source in 2016 is shown in Table 1 (computed and constructed by the author by data $[5 ; 6])$.

Table 1

Scopes of emittions of methane and ammonia by natural-economic zone, region and source, 2016

\begin{tabular}{|c|c|c|c|c|c|c|c|}
\hline \multirow[b]{2}{*}{ Region } & \multirow[b]{2}{*}{$\begin{array}{l}\text { Number of } \\
\text { agriculture } \\
\text { enterprises }\end{array}$} & \multirow{2}{*}{$\begin{array}{c}\text { Average } \\
\text { emission } \\
\text { per } \\
\text { enterprise, } \\
\text { ton } \\
\end{array}$} & \multicolumn{5}{|c|}{ Scopes of emissions from, ton } \\
\hline & & & $\begin{array}{c}\text { intestinal } \\
\text { fermentation }\end{array}$ & dung & broilers & milk cows & $\begin{array}{c}\text { other } \\
\text { categories } \\
\text { of cattle }\end{array}$ \\
\hline Dnipropetrovsk & 28 & 54,93 & 478,57 & 861,21 & 8,10 & 3,91 & 0,77 \\
\hline Donetsk & 29 & 50,00 & 836,84 & 71,54 & 2,32 & 75,47 & - \\
\hline Zaporizhzhia & 34 & 38,48 & 723,88 & 254,91 & - & 227,40 & 1,40 \\
\hline Kirovohrad & 48 & 15,10 & 455,44 & 127,18 & - & 23,53 & 12,89 \\
\hline Luhansk & 24 & 25,00 & 99,67 & 73,98 & - & 13,74 & 23,42 \\
\hline Mykolaiv & 43 & 18,80 & 109,93 & 268,36 & - & 58,01 & 14,86 \\
\hline Odesa & 52 & 13,25 & 276,74 & 174,38 & - & 127,03 & 80,78 \\
\hline Kherson & 25 & 30,73 & 552,04 & 159,64 & - & 163,59 & 166,43 \\
\hline Steppe zone & 283 & 30,79 & 3533,08 & 1991,20 & 10,42 & 692,68 & 300,55 \\
\hline Vinnytsia & 85 & 252,07 & 2385,87 & 15222,36 & 231,58 & 960,24 & 744,82 \\
\hline Kyiv & 73 & 74,93 & 3806,11 & 342,7 & 1731,16 & 466,61 & 36,35 \\
\hline Poltava & 85 & 88,54 & 4591,82 & 1787,58 & - & 1962,17 & 1783,95 \\
\hline \begin{tabular}{|l|} 
Sumy \\
\end{tabular} & 53 & 22,16 & 251,03 & 181,59 & - & 121,62 & 24,54 \\
\hline Ternopil & 73 & 31,62 & 917,36 & 760,87 & 5,60 & 223,59 & 362,48 \\
\hline Kharkiv & 56 & 30,62 & 369,12 & 355,10 & 58,32 & 31,45 & 10,21 \\
\hline Khmelnytskyi & 43 & 72,08 & 512,84 & 187,13 & 0,54 & 196,63 & 84,91 \\
\hline Cherkasy & 153 & 73,50 & 11121,38 & 3216,84 & 4987,32 & 2921,85 & 2660,69 \\
\hline Chernivtsi & 20 & 29,25 & 288,70 & 84,11 & - & - & - \\
\hline $\begin{array}{l}\begin{array}{l}\text { Forest-Steppe } \\
\text { zone }\end{array} \\
\end{array}$ & 641 & 74,90 & 24244,23 & 22138,28 & 7014,52 & 6884,16 & 5707,96 \\
\hline Volyn & 35 & 26,14 & 143,06 & 614,94 & - & 16,50 & 8,88 \\
\hline Zhytomyr & 40 & 64,42 & 900,64 & 549,28 & - & 548,96 & 322,23 \\
\hline Zakarpattia & 4 & 2,86 & 723,88 & - & - & - & - \\
\hline Ivano-Frankivsk & 30 & 69,45 & 1137,49 & 729,66 & 29,31 & & 66,20 \\
\hline Lviv & 40 & 42,57 & 575,70 & 274,11 & 268,09 & 42,028 & - \\
\hline Rivne & 29 & 26,59 & 192,96 & 58,05 & 7,25 & 41,02 & 140,26 \\
\hline Chernihiv & 193 & 56,47 & 6784,15 & 3461,67 & - & 3041,38 & 3595,52 \\
\hline Polissia zone & 371 & 41,20 & 10457,90 & 5687,71 & 304,65 & 3689,87 & 4133,09 \\
\hline Ukraine's total & 1297 & 62,91 & 37694,80 & 29822,18 & 7339,12 & 11266,72 & 10141,59 \\
\hline
\end{tabular}

The computations show that emissions of ammonia and methane in Forest-Steppe economic zone have the largest share in the total emission of dangerous substances from agricultural production. This zone accounts for $64.3 \%$ emissions of intestinal fermentation of animals, $74.2 \%$ emissions from formation, storage and use of dung, 95.6\% emissions from breeding of broilers, $61.1 \%$ emissions from breeding of milk cows, and $56.3 \%$ emissions from breeding other cattle. In overall, the largest share of emissions of ammonia and methane is due to intestinal fermentation of animals and formation, storage and use of dung give. 
The statistical assessment of emissions of dangerous substances from agricultural activities of enterprises by natural-economic zone and region shows that a significant part, i.e. more than the half of the total, of air emissions is generated by agricultural producers in Forest-Steppe economic zone, and the least part of them is generated in Steppe zone.
The further statistical studies should be focused on detailed analysis of air emissions of dangerous substances from agricultural enterprises by sector. Their results will contribute in taking effective environmentally friendly management decisions on developing and reporting of environmental indicators in the agricultural sector.

\section{References}

1. Khvesyk, M. A., Stepanenko, A. V., \& Obikhod, H. O., et al. (2014). Ekolohichna ipryrodno-tekhnohenna bezpeka Ukrainy $v$ rehionalnomu vymiri [The economic and natural-industrial safety in Ukraine in the regional perspective]. M. A. Khvesyk (Ed.). Kyiv: DU "Instytut ekonomiky pryrodokorystuvannia ta staloho rozvytku NAN Ukrainy" [in Ukrainian].

2. Libanova, E. M., \& Khvesyk, M. A. (Eds.) (2017). Sotsialno-ekonomichnyi potentsial staloho rozvytku Ukrainy ta yii rehioniv: vektory realnoho postupu: natsionalna dopovid [The socio-economic potential of the sustainable development in Ukraine and its regions: vectors of real progress: a national report]. Kyiv: DU IEPSR NAN Ukrainy [in Ukrainian].

3. Stepanenko, A. V., Obikhod, H. O., \& Omelchenko, A. A., et al. (2016). Ekolohichna modernizatsiia v systemi okhorony atmosfernoho pozitria v rehionakh Ukrainy [The economic modernization in the air protection system in Ukrainian regions]. Kyiv: DU IEPSR NAN Ukrainy [in Ukrainian].

4. Zubets, M. V. (Head of Edit. Board). (2004). Naukovi osnovy ahropromyslovoho vyrobnytstva v zoni Polissia ta zakhidnoho rehionu Ukrainy [The scientific grounds of agro-industrial production in the zone of Polissya and Western region of Ukraine]. Kyiv: Urozhai [in Ukrainian].

5. Statystychnyi shchorichnyk Ukrainy za 2016 rik [Statistical Yearbook of Ukraine 2016]. (2017). ukrstat.gov.ua. Retrieved from https://ukrstat.org/uk/druk/publicat/kat_u/publ1_u.htm [in Ukrainian].

6. Dovkillia Ukrainy za 2016 rik [Environment of Ukraine 2016: Statistical Yearbook]. (2017). ukrstat.org. Retrieved from http://www.ukrstat.gov.ua/druk/publicat/kat_u/publnav_ser_u.htm [in Ukrainian].

7. Nakaz Derzhavnoho komitetu statystyky Ukrainy vid 05.08.2011 r. № 198 "Pro zatverdzhennia Metodolohichnykh polozhen z orhanizatsii derzhavnoho statystychnoho sposterezhennia shchodo okhorony atmosfernoho povitria" [Order of the State Statistics Committee of Ukraine of April 5, 2011, No 198 On Approval of Methodological Regulations on the Organization of State Statistical Survey on the Protection of the Atmospheric Air]. wrere.ukrstat.gov.ua. Retrieved from http://www.ukrstat.gov.ua/metod_polog/metod_ doc/2011/198/198.htm [in Ukrainian].

8. Nakaz Derzhavnoi sluzhby statystyky Ukrainy vid 23.03.2016 r. № 44 "Pro zatverdzhennia Metodolohichnykh polozhen $\mathrm{z}$ orhanizatsii derzhavnoho statystychnoho sposterezhennia $\mathrm{z}$ okhorony atmosfernoho povitria" [Order of the State Statistics Service of Ukraine of March 23, 2016, No 44 "On Approval of Methodological Regulations on the Organization of State Statistical Survey on the Protection of the Atmospheric Air"]. wrwro.ukrstat.gov.ua. Retrieved from http://www.ukrstat.gov.ua/metod_polog/metod_ doc/2016/44/44_2016.htm [in Ukrainian].

9. Zakon Ukrainy "Pro okhoronu navkolyshnoho pryrodnoho seredovyshcha” vid 25.06.1991 r. № $1264-$ XII [The Law of Ukraine of June 25, 1991, No 1264-XII "On protection of natural environment" as of April 22, 2018]. zakon2.rada.gov.ua. Retrieved from http://zakon2.rada.gov.ua/laws/show/1264-12 [in Ukrainian].

10. Dovkillia Ukrainy za 2012 rik [Environment of Ukraine 2012: Statistical Yearbook]. (2013). ukrstat.org. Retrieved from https://ukrstat.org/uk/druk/publicat/Arhiv_u/07/Arch_dov_zb.htm [in Ukrainian].

\section{T. В. Кобилинська,}

кандидат економічних наук,

докторант кафедри статистики,

Національна академія статистики, обліку та аудиту

\section{Статистична оцінка викидів небезпечних речовин від сільськогосподарської діяльності підприємств в атмосферне повітря: регіональний аспект}

Процес аграрної та земельної реформи в нашій країні триває не одне десятиліття. Хоча реформування агропромислового комплексу в Україні зумовило стабільну позитивну динаміку виробництва сіль- 
ськогосподарської продукції, поряд з цим зросли й обсяги викидів небезпечних речовин від цієї діяльності. Збереження навколишнього природного середовища та зменшення викидів небезпечних речовин є однією з пріоритетних проблем сьогодення. Водночас низький рівень інформаційного забезпечення та законодавча неврегульованість неминуче призводять до кризи мотивації екологічної діяльності сільськогосподарських підприємств. Проблемні питання статистичного оцінювання екологічних наслідків сільськогосподарської діяльності підприємств, зокрема секторальний аналіз обсягів викидів за природно-економічними зонами, наразі є невирішеними. Дослідження шляхів їх розв’язання набуває вагомого значення для екологічної політики держави, оскільки проведення порівняльного статистичного аналізу сільськогосподарського виробництва за природно-економічними зонами дозволить приймати виважені політично-екологічні рішення.

У роботі проведено статистичний аналіз викидів небезпечних речовин від окремих процесів сільськогосподарської діяльності за природно-економічними зонами, а саме: Степом, Лісостепом, Поліссям. Проведено ранжування регіонів за кількістю сільськогосподарських підприємств, які мали викиди небезпечних речовин, та обсягами викидів. Зазначено, що забруднення атмосферного повітря за ступенем хімічної небезпеки для людини посідає перше місце і справляє суттєвий негативний вплив на всі компоненти довкілля. За регіонами країни розглянуто обсяг викидів таких небезпечних речовин: оксид азоту; аміак; діоксид сірки; оксид вуглецю; неметанові леткі органічні сполуки. Щодо викидів метану й аміаку проаналізовано іх розподіл за джерелами утворення, серед яких кишкова ферментація тварин; утворення, зберігання та використання гною; утримання молочних корів, іншої великої рогатої худоби та бройлерів. Встановлено, що провідне місце у викидах небезпечних речовин належить підприємствам, розташованим у лісостеповій природно-економічній зоні України.

Вказано на необхідність детального аналізу викидів небезпечних речовин в атмосферне повітря від сільськогосподарської діяльності підприємств за галузевим розподілом.

Ключові слова: обсяги викидів, сільськогосподарське виробництво, небезпечні речовини, природноекономічні зони, статистичне оцінювання.

\section{T. В. Кобылинская,}

кандидат экономических наук, докторант кафедры статистики,

Национальная академия статистики, учета и аудита

\section{Статистическая оценка выбросов опасных веществ от сельскохозяйственной деятельности предприятий в атмосферный воздух: региональный аспект}

Показаны результаты статистической оценки выбросов опасных веществ от сельскохозяйственной деятельности предприятий по регионам и природно-экономическим зонам Украины (Степь, Лесостепь и Полесье). Выполнена оценка регионов по количеству сельскохозяйственных предприятий с выбросами опасных веществ и объемам выбросов. Установлено, что наибольшие объемы выбросов опасных веществ производятся предприятиями, расположенными в лесостепной экономической зоне Украины.

Ключевые слова: объемы выбросов, сельскохозяйственное производство, опасные вещества, природноэкономические зоны, статистическая оценка.

Bibliographic description for quoting:

Kobylynska, T. V. (2018). Statistical Assessment of Air Emission of Dangerous Substances from Agricultural Activities: the Regional Aspect. Statystyka Ukrainy - Statistics of Ukraine, 2, 82-88 [in English].

Бібліографічний опис для цитування:

Кобилинська Т. В. Статистична оцінка викидів небезпечних речовин від сільськогосподарської діяльності підприємств в атмосферне повітря: регіональний аспект // Статистика України. 2018. № 2. С. 82-88. 